\title{
Correction to: Symptoms of anxiety disorders in Iranian adolescents with hearing loss during the COVID-19 pandemic
}

\author{
Saeed Ariapooran ${ }^{1 *}$ and Mehdi Khezeli ${ }^{2}$
}

\author{
Correction to: BMC Psychiatry 21, 114 (2021) \\ https://doi.org/10.1186/s12888-021-03118-0
}

Following the publication of the original article [1], minor errors were identified in the sections. The changes have been highlighted in bold typeface.

Abstract:

Results

Among the subscales, only the Social Anxiety Disorder (39.1\% in deaf vs. 9.1\% in HH, $p=0.009$ ) and the School Avoidance $(52.2 \%$ in deaf vs. $24.2 \%$ in $\mathrm{HH}, p=0.031$ ) significantly differed.

Background:

According to the World Health Organization, Iran is the leading country in the number of cases and deaths due to COVID-19 in the Eastern Mediterranean region [2].

Results:

Symptoms of $A D s$

Among the subscales only SoAD $(39.1 \%$ in deaf vs. 9.1\% in HH, $P$-value $=0.009)$ and SA $(52.2 \%$ in deaf vs. $24.2 \%$ in $\mathrm{HH}, p$-value $=0.03$ ) significantly were higher in the deaf adolescent than $\mathrm{HH}$ peers.

The author group has been updated above and the original article [1] has been corrected.

\begin{abstract}
Author details
${ }^{1}$ Department of Psychology, Malayer University, Malayer, Iran. ${ }^{2}$ Social Development and Health Promotion Research Center, Health Institute, Kermanshah University of Medical Sciences, Kermanshah, Iran.
\end{abstract}

Published online: 09 April 2021

\section{Reference}

1. Ariapooran, Khezeli. Symptoms of anxiety disorders in Iranian adolescents with hearing loss during the COVID-19 pandemic. BMC Psychiatry. 2021;21: 114. https://doi.org/10.1186/s12888-021-03118-0.

The original article can be found online at https://doi.org/10.1186/s12888 021-03118-0.

* Correspondence: s.ariapooran@malayeru.ac.ir

${ }^{1}$ Department of Psychology, Malayer University, Malayer, Iran

(c) The Author(s). 2021 Open Access This article is licensed under a Creative Commons Attribution 4.0 International License, which permits use, sharing, adaptation, distribution and reproduction in any medium or format, as long as you give appropriate credit to the original author(s) and the source, provide a link to the Creative Commons licence, and indicate if changes were made. The images or other third party material in this article are included in the article's Creative Commons licence, unless indicated otherwise in a credit line to the material. If material is not included in the article's Creative Commons licence and your intended use is not permitted by statutory regulation or exceeds the permitted use, you will need to obtain permission directly from the copyright holder. To view a copy of this licence, visit http://creativecommons.org/licenses/by/4.0/ The Creative Commons Public Domain Dedication waiver (http://creativecommons.org/publicdomain/zero/1.0/) applies to the data made available in this article, unless otherwise stated in a credit line to the data. 